\title{
High-resolution 3D-seismic data indicate focussed fluid migration pathways above polygonal fault systems of the mid-Norwegian margin
}

\author{
Steinar Hustoft ${ }^{a}{ }^{*}$, Jürgen Mienert ${ }^{a}$, Stefan Bünz ${ }^{a}$ and Hervé Nouzé ${ }^{b}$ \\ a Department of Geology, University of Tromsø, Dramsvn. 201, 9037 Tromsø, Norway \\ ${ }^{\mathrm{b}}$ Ifremer Centre de Brest, Géosciences Marines, BP 70, 29280 Plouzané Cedex, France \\ *: Corresponding author : Steinar Hustoft, email address : $\underline{\text { Steinar.Hustoft@ig.uit.no }}$
}

\begin{abstract}
:
Seismic attribute analysis and interpretation of high-resolution 3D- and 2D-seismic data reveal focussed fluid flow processes through the gas hydrate stability zone (GHSZ) at the northern flank of the giant Storegga Slide. Diffusive fluid migration predominantly starts from a widespread polygonal fault system in fine-grained sediments of the Miocene Kai Formation. The overlying 600-700 m thick Plio-Pleistocene Naust Formation shows spatially related soft-sediment deformation and overlying fluid conduits. A low relief antiform structure connects to an overlying $250 \mathrm{~m}$ high, $300 \mathrm{~m}$ wide and 3 $\mathrm{km}$ elongated columnar zone, where seismic signatures suggest self-enhanced permeability, i.e. natural hydraulic fracturing. "Push-down" effects create an elongated depression caused by increased gas accumulations where a cluster of vertical cylindrical acoustic pipe structures originates. These pipe clusters pierce the GHSZ and indicate focussed fluid flow pathways originating from potentially overpressured sediments. High seismic reflection amplitudes at the seafloor above the pipe structures may indicate pockmarks with authigenic carbonates and/or gas hydrates. The observed objects and seismic features presented are not stand-alone indicators for fluid flow, but a joint perspective illustrates that they are vertically tied together providing new insights to the effects of focussed fluid flow.
\end{abstract}

Keywords: Norwegian margin; polygonal faulting; hydraulic fracturing; feeding of methane to hydrate deposits; acoustic pipes and pockmarks 


\section{INTRODUCTION}

The formerly glaciated mid-Norwegian passive continental margin has received considerable attention during the last decades in terms of hydrocarbon prospectivity (Bryn et al., 1998), submarine sliding (Bugge et al., 1988; Mienert et al., 2005; Solheim et al., 2005a; 2005b), fluid migration processes (Berndt et al., 2003; Svensen et al., 2004; Hovland et al., 2005; Mazzini et al., 2006), shallow gas and gas hydrate accumulations (Mienert et al., 1998; Bouriak et al., 2000; 2001; Bünz et al., 2003; 2005). This research has predominantly investigated the close relationship between one of the world's largest submarine slides, the Storegga Slide, and the dynamic behavior of oceanic gas hydrates and fluid flow (Fig. 1) (Vogt and Yung, 2002; Milkov et al., 2004; Mienert et al., 2005).

Approximate location of Figure 1.

Oceanic gas hydrates occur globally in a variety of geographical, oceanographical and geological environments on active and passive continental margins (Kvenvolden, 1993a; 1993b). Gas hydrates are ice-like crystals consisting of a rigid cage of water molecules that entrap hydrocarbon and non-hydrocarbon gas by hydrogen bonding. They occur naturally in the pore space of different types of marine and lacustrine sediments, where appropriate pressure, temperature, and salinity (PTS) conditions, and sufficient supplies of gas (mainly methane) and water exist (Sloan, 1998). Those requirements confine oceanic gas hydrates to the upper few hundred meters of the sediments on continental margins, which is called the 'gas hydrate stability zone' (GHSZ). The 'base of the gas hydrate stability zone' (BGHSZ) 
represents the phase boundary between stable gas hydrates and free gas below (Holbrook et al., 1996) indicated by a bottom simulating reflection called BSR (Shipley et al., 1979).

Gas hydrate accumulations depend on complex hydrologic systems controlled by factors such as fluid flux rates, methane solubility and distribution of the sediment properties, for example, porosity and grain size (Nimblett and Ruppel, 2003). Gas hydrates accumulate in the pore spaces of the sediment and reduce porosity and permeability (Nimblett and Ruppel, 2003), which in turn alters the flux of fluids through the hosting sediment. Heterogeneous allocation of gas hydrates within the GHSZ may be controlled by specific fluid flow pathways. Fluid escape features are often associated with gas hydrate systems in both low and high flux margin settings (i.e. passive and active margins) (Suess et al., 1999). Long-term seeping gases through the seafloor at these vent sites are the primary source for chemosymbiotic communities and precipitation of authigenic carbonates (Hovland et al., 2005; Mazzini et al., 2006).

Observations and experimental research shows that fluid migration tends to be focussed through discrete migration pathways such as faults or vertical expulsion features (i.e. chimneys and diapirs), though a major part of the flow may be diffusive (Berndt, 2005). Overpressured fluids within sediments provide one of the main driving mechanisms for sediment fracturing. If the pore-fluid pressure in sedimentary basins exceeds the least principal stress and the tensile strength of the host rock, the pore pressure itself may initiate fractures called 'natural hydraulic fracturing' (Hubbert and Willis, 1957; Secor, 1965; Luo and Vasseur, 2002). Once the fractures are created they may remain as fluid escape pathways (Mazzini et al., 2003). Hydraulic fracturing is also believed to be a trigger mechanism for the onset of mud diapirism (Dimitrov, 2002). However, fluid flow pathways can be diverse and are presently not fully understood despite various observations.

Based on the interpretation of high-resolution 3D-seismic data we identify and describe numerous fluid conduits occurring from the basal units of the Plio-Pleistocene Naust Formation towards the seafloor, covering stratigraphic units of 600-700 m with hemipelagic and glaciomarine sediments. We draw special attention to the feeding of fluids from the top of a polygonal fault system towards the gas hydrate stability zone, and show that hydraulic fracturing is an important process, previously not reported from this area. Based on the new findings, we propose a conceptual model that involves favorable locations for focussed fluid migration and trigger mechanisms in a dynamic system with a potential for gas hydrate plumbing.

\section{REGIONAL GEOLOGICAL SETTING}

The formerly glaciated passive mid-Norwegian continental margin developed during several repeated rifting periods since Permian times. The final continental break-up in the late Paleocene-early Eocene ( $55 \mathrm{Ma})$ and subsequent thermal subsidence, led to the development of the Vøring and Møre sedimentary basins (Brekke and Riis, 1987; Skogseid et al., 1992; Brekke, 2000). Eocene-middle Miocene compressional activity led to the formation of $\mathrm{N}-\mathrm{S}$ elongated anticline structures (Figs. 1 and 2) (Doré and Lundin, 1996; Vågnes et al., 1998). These anticlines are structural traps for potential hydrocarbon reservoirs, e.g. the Ormen Lange Dome (Bryn et al., 1998). Bünz et al. (2005) suggested that hydrocarbons leaking from the Ormen Lange gas reservoir supply thermogenic methane to the GHSZ, which contributes to hydrate formation, shallow gas accumulations and pore-pressure build-up. An equivalent structure to the Ormen Lange dome, called the Helland-Hansen Arch, is located in the subsurface of our study area. The area indicates the presence of gas shows (Fig. 1; Wellbore 6505/10-1), but it proved to be of poor reservoir quality and of non-economic value for the petroleum industry. However, the drilling confirms that thermogenic gas is present in the subsurface, which may be involved in the fluid flow system in our study area as well. 
Approximate location of Figure 2.

The fluid flow system investigated in this study is located within the sedimentary successions of the late Miocene - early Pliocene Kai Formation and the Plio-Pleistocene Naust Formation (Fig. 2). Fine-grained hemipelagic siliceous ooze generally characterizes the Kai Formation (Rokoengen et al., 1995). Polygonal faults are typical for the Kai Formation on the Vøring margin (Hjelstuen et al., 1997; Berndt et al., 2003), a process possibly related to compaction and dewatering due to gravitational loading (Cartwright and Lonergan, 1996). The Naust Formation comprises the Plio-Pleistocene glacial-interglacial climate cycles where large amounts of sediments were supplied to the continental slope due to the waxing and waning of the Fennoscandian ice sheet (Sejrup et al., 2004). Hemipelagic-, glaciomarine-, and contouritic clays correspond to sediments deposited during the interglacial periods. These deep water deposits are interbedded by seaward pinching wedges of 'glacigenic debris flow' (GDF) (Dalland et al., 1988; Hjelstuen et al., 2005) that locally are $350 \mathrm{~ms}$ (TWT) thick (Fig. 2). They correspond to periods of grounded ice sheets during maximum glaciations. Seismic correlation (Hjelstuen et al., 2004a; Rise et al., 2005) and a shallow borehole (6404/5GB1; Fig. 1 and 2) indicate that the upper and lower Naust unit, unit O, corresponds to Weichselian and Saalian glacial times, respectively, separated by a regional reflector of Eemian interglacial age (Intra Naust O, 120 ka). Naust unit R correlates to the Elsterian glacial period of marine isotope stage 8-10. Borehole data show that the upper section of Naust unit $\mathrm{S}$ is composed of hard clay with relatively high organic debris content and high pore water content compared to the overlying units (NGI, 1997). The basal unit of the Naust Formation, unit $\mathrm{W}$, is not penetrated by the geotechnical borehole.

A gas hydrate related bottom-simulating reflection (BSR) in the study area mimics the seafloor and cross-cuts the Naust Formation sediments at approximate $350 \mathrm{~ms}$ (TWT) subsurface depth (Fig. 3) (Bünz et al., 2003). The BSR is recognized by a reversed polarity when compared to the seafloor reflection. The reversed polarity is caused by a low velocity zone that is due to free gas accumulations beneath the GHSZ. The regional distribution of the BSR at the upper continental slope is confined by the water depth (hydrostatic pressure) and lithological properties such as low permeable GDF deposits, which prevent formation of gas hydrates (Bünz et al., 2003).

\section{SEISMIC DATA AND METHODS}

The "Hydratech"-project of the European Union $5^{\text {th }}$ Framework program collected high-resolution 3D-seismic data during a cruise, led by Ifremer, to the mid-Norwegian margin in 2002 (Fig. 1) (Nouzé et al., 2004). The 3D-seismic dataset cover an area of $\sim 28 \mathrm{~km}^{2}$ located in water depths between $1050 \mathrm{~m}$ and $1150 \mathrm{~m}$. The bin size $(\sim 6 \mathrm{~m})$ of the 3D-dataset and the dominant frequency $(\sim 80 \mathrm{~Hz})$ provides an appreciable horizontal and vertical resolution compared to conventional industry 3D-seismic data. A detailed description of the acquisition system has been published by Thomas et al. (2004).

Two regional multi-channel 2D-seismic lines are used to complement the 3D-seismic interpretation (Fig. 1). A SW-NE oriented high-resolution 2D-seismic profile (NH9651-202; dominant frequency $85 \mathrm{~Hz}$ ) runs along the centre inline of the 3D-seismic data covering water depths from 800 to $1400 \mathrm{~m}$. The other profile (SG9711-115B; dominant frequency $50 \mathrm{~Hz}$ ) runs $\mathrm{E}-\mathrm{W}$, and it is located $\sim 3 \mathrm{~km}$ north of the 3D-seismic area.

Seismic attributes such as instantaneous frequency and volumetric attribute maps are used to determine the geological structures, principal sediment properties and infer pore-fluids in the subsurface. In the following section we briefly describe the seismic attributes. The seismic horizon attribute Instantaneous frequency is the first derivative of the Instantaneous Phase, and is independent of the reflections strength. Instantaneous frequency can be used to detect areas of variable seismic attenuation, as free gas in the pore space absorbs seismic 
energy due to internal friction. The amplitude loss of a P-wave depends on the amount of wave cycles along the ray path. In a given region of free gas accumulation, $\mathrm{P}$-waves of shorter wavelength energy (i.e. high frequency) will be more attenuated. Consequently, reflection arrivals from areas that underlie regions of high attenuation often show a reduction of high frequency components of the acoustic energy (Taner et al., 1979; Yilmaz, 1987). The minimum value - seismic amplitude is a volume based attribute. It detects the lowest seismic amplitudes for each trace in a defined volume, and displays that amplitude in the corresponding grid cell. This attribute is useful to identify negative amplitude bright spots and potential low velocity medium, often indicative of hydrocarbons.

\section{RESULTS}

The 2D-seismic line NH9651-202 (Fig. 3) illustrates the major stratigraphic units and geological structures of the subsurface in the study area. The main structural and acoustic features are from bottom to top; the Tertiary Helland Hansen Arch, polygonal faulting in the Miocene Kai Formation, a thick acoustic transparent interval in the lower section of the Naust Formation, and a zone of enhanced reflections underneath the BGHSZ defined by a BSR. Several, more than $400 \mathrm{~ms}$ (TWT) long, vertical acoustic pipes are primarily confined to Naust units $\mathrm{O}$ and $\mathrm{R}$.

Approximate location of Figure 3.

\subsection{Fluid flow in Kai and lower Naust formations}

Figures 2 and 3 demonstrate a westward decrease in polygonal faulting together with a decreasing thickness of the Kai Formation on the eastern side of the Helland-Hansen Arch. Naust unit W overlays the Kai Formation and is characterized by down-slope dipping conformable reflections with progressively decreasing amplitudes towards the NE (Fig. 3). The low amplitudes are most likely related to attenuation of the seismic energy caused by the overlying enhanced reflections in the Naust unit R (section 4.2). Time-structure relief maps of horizons within Naust unit W indicate the presence of a $2.5 \mathrm{~km}$ elongated N-S trending structure with a positive relief in the 3D-seismic area, occurring at approximate $700 \mathrm{~ms}$ (TWT) below the seafloor (Fig. 4a). The elongated positive relief can, in a three-dimensional perspective, be characterized as an antiform structure that is most prominent at the top Naust $\mathrm{W}$ horizon. This antiform structure reaches a maximum height (elevation when compared to the adjacent areas) of $5 \mathrm{~ms}$, but is $3 \mathrm{~ms}$ on average, and the width varies from $120 \mathrm{~m}$ to $190 \mathrm{~m}$ (Figs. 4a and 4c). Similar structures with positive relief are observed on numerous 2D-seismic cross-sections throughout the study area, as for example seen on the $\mathrm{E}-\mathrm{W}$ oriented section in figure 5. This 2D-seismic profile is located $3 \mathrm{~km}$ north of the $3 \mathrm{D}$-seismic cube, but these structures occur at the same reflector with comparable height-to-width aspect ratios. On crosssections, these positive relief structures occur with a semi-regular spacing, which frequently can be traced to underlying polygonal faults positioned at various depths (Fig. 5). Hence, there may be a potential link between the origin of these structural styles and underlying polygonal faults. However, a solid interpretation of the link between the antiform structures and the polygonal faults is difficult to establish due to the coarse 2D-seismic grid and the limited penetration depth of the 3D-seismic dataset (max penetration of 2.15 seconds).

Approximate location of Figure 4.

Approximate location of Figure 5.

Naust unit $\mathrm{S}$ is approximately $250 \mathrm{~m}$ thick based on an average P-wave velocity of $2000 \mathrm{~m} \mathrm{~s}^{-1}$. Naust unit $\mathrm{S}$ is a massive unit characterized by weak reflection amplitudes with less lateral reflection continuity compared to overlying units (Figs. 3, 4c, and 5). As low reflection amplitudes of this unit only correspond to areas where sections of high-amplitude reflections are present above, the observed amplitude reduction is attributed to absorption and 
attenuation of the seismic energy. A $3 \mathrm{~km}$ long, $300 \mathrm{~m}$ wide, and $250 \mathrm{~m}$ high N-S trending 'volume' of anomalous discontinuous and disturbed reflections can be traced vertically throughout the entire Naust unit $S$ where it terminates immediately at the base of the enhanced reflections (Fig. 4c). The acoustic turbidity and randomly distributed bright spots that occur within this zone, suggest a non-depositional origin for the anomalous reflection signature. The instantaneous frequency map generated from the Top Naust W horizon shows an area with anomalous loss in high frequencies (Fig. 4b). The region of reduced frequencies correlates to the elongated antiform structure, indicating a dominance of acoustic attenuation related to the columnar disturbed zone. The degree of seismic attenuation with depth may depend on the presence of gas in the pore-fluid of the sediments. In the case of pore-fluids with low density and velocity properties (free gas in fluids), acoustic wave amplitudes and their high frequency content decrease drastically. The low frequency content suggests that gassy fluids are associated with the area of disturbed reflection signature when compared to the background areas of the Naust unit $\mathrm{S}$.

Top Naust unit S represents the base of a section of high amplitude reflections (Fig. 5). No structural elements occur at this stratigraphic level, except for a $3 \mathrm{~km}$ long structure with a negative relief that is oriented N-S (Fig. 4a). The relief of the depression increases from $5 \mathrm{~ms}$ in the north to $13 \mathrm{~ms}$ (TWT) in the south, and the width varies between 100-180 m from north to south, respectively. This elongated depression is located precisely on top of the extended area/volume with anomalous discontinuous and disturbed reflection signature (Figs. 4a and 4c). The strong spatial correlation between structural and acoustic elements in the Naust W, Naust $\mathrm{R}$ and Naust $\mathrm{S}$ units suggests that these elements results from vertical channeling of fluids (Figs. 4 and 5). In that case, fractures are expected to be present at scales less than seismic resolution (i.e. theoretical vertical resolution is $8-10 \mathrm{~m}$ ), which act as potential fluid conduits.

\subsection{BSR and enhanced seismic reflections}

The bottom-simulating reflection (BSR) is not a continuous reflection that is often observed elsewhere (e.g. Hydrate Ridge). Instead, high reflection amplitudes of gently dipping layers in Naust unit $\mathrm{R}$ show an abrupt amplitude decrease down-slope, which mimics the seafloor (Figs. 3, 5 and 6). The volumetric attribute map in Figure 7 shows the distribution of the minimum seismic amplitudes over a $100 \mathrm{~ms}$ (TWT) interval in the region of the BSR. High negative seismic amplitudes (red, yellow and green colors) are located in NW - SE along-slope striking belts. The attribute map demonstrates the abrupt down-slope termination of high negative seismic amplitudes in plan view, representing the exact lateral location of the BSR within the 3D-seismic area. The instantaneous frequency display (Fig. 6b) and the volume based attribute map (Fig. 7) also indicate the presence of vertical low frequency zones and semi-circular amplitude wipe-out zones, respectively.

Approximate location of Figure 6 and 7.

\subsection{Vertical acoustic pipe clusters}

A number of geological structures within the 3D-seismic dataset provide evidence for focussed fluid flow. However, the most prominent features stem from seismic signatures of vertical and narrow zones of acoustic wipe-out with upward bending marginal reflections (Fig. 3). These structures are often referred to as acoustic "pipes" (Løseth et al., 2001) or gas chimneys, which are often associated with pockmarks at present day seafloors world-wide (Hovland and Judd, 1988). In the following, we refer to these structures as acoustic pipe structures, as their real cause is unclear. In plan views and perspective views, the vertical wipe-out zones are characterized as elliptical cylinders (Fig. 4a and 7). Five acoustic pipes are identified within the high-resolution 3D-seismic area (labeled P1-P5 in Figure 4a and 6, see 
also Table 1). Northeast of the 3D-seismic area, three additional pipes are identified on the regional 2D-seismic profile (labeled P6-P8 in Figure 3, see also Table 1). Based on the longitudinal axis of the elliptical cylinder geometries, map view orientations of individual pipe structures can be determined. The five investigated pipe structures (P1-P5) have longitudinal axes all running parallel to each other, oriented NW-SE. Also, three pipe structures, P2, P3, and P4, are aligned in one string parallel to the orientation of their longitudinal axis. The pipes investigated vary between $60-130 \mathrm{~m}$ in diameter. Some pipe structures reach a maximum of 6-8 ms of reflection pull-up towards their central zone, which progressively decreases with depth. It is not clear if the pull-up reflection signatures represent real structures or if they correspond to pseudo-velocity structures. In case of a velocity effect, the pull-up seismic signature implies that the pipe holds sediments of higher acoustic velocities near the seafloor compared to adjacent areas (i.e. authigenic carbonate or gas hydrate hosting sediments). Push-downs within such pipe structures are commonly associated with anomalous low P-wave velocities, suggesting the presence of free gas. Structural effects, off-course, imply that the pipes can correspond to mud diapirism.

Exact depth determinations of the base of the acoustic pipe structures are difficult, because the amplitude wipe-out gradually vanishes with depth. However, every pipe structure is traceable and occurs as a prominent feature at the base of the enhanced reflections at horizon Top Naust S. Except for pipe structures P2, P3, and P4 within the 3D-seismic dataset, all the pipes are somewhat affiliated to the area below the Top Naust $\mathrm{S}$ horizon. The largest prominent pipe structure within the 3D-seismic dataset (P1) is even distinguishable to $2.15 \mathrm{~s}$ TWT at the base of the dataset (Fig. 6). In contrast to the base of the pipe structures, upper terminations are well defined by the Intra Naust O reflector, except for pipe P6 that reaches the seafloor (Fig. 3). The 2D-seismic profile in figure 3 indicates that pipe P6 terminates at the seafloor (Table 1). However, no geometric relief can be observed, e.g. pockmark or mound. Instead, impedance contrast strongly increases as documented by the high reflection amplitudes. Observations with pipe structures that relate to high impedance contrasts on the seafloor have previously been reported in the same area (Thomas et al., 2004). No pipes pierce the gas hydrate stability zone (GHSZ) at the central BSR area (i.e. down-slope termination of enhanced reflections), where the gas hydrate concentration reaches its maximum (Bünz and Mienert, 2004). The density of acoustic pipe structures accumulates within a $9 \mathrm{~km}$ wide belt, bounded by the prominent BSR in the southwest and the wedge of GDF deposits in the northeast.

A striking observation is that the identified pipe structures cluster in the vicinity of the observed elongated depression (Fig. 4a). An elongated negative relief of this character, overlying a potential fluid conduit, may be attributed to a palaeo fluid expulsion structure caused by gas-turbation. Alternatively, the elongated depression may correspond to a pseudovelocity structure, a push-down, indicating an active fluid expulsion feature (see section 5.3).

\section{DISCUSSION}

\subsection{Structural control on fluid flow in Kai and lower Naust formations}

The subsequent fluid expulsion caused by sediment contraction is referred to as dewatering in fine-grained sediments (Cartwright and Dewhurst, 1998), and it is an important process in the context of gas hydrate systems. Berndt et al. (2003) indicated that dewatering and development of polygonal faults within the Kai Formation and the underlying Brygge Formation may be a source for fluids that contributes to gas hydrate formation in this part of the Vøring margin (Fig. 1). Once created, the faults are considered to be potential fluid conduits. Development of polygonal faulting in response to syneresis of colloidal sediments (Cartwright and Lonergan, 1996) and compaction caused by gravitational loading (Goulty and Swarbrick, 2005) are commonly inhibited by the larger grain size and fabric of Naust 
Formation sediments. However, indefinite displacement of layers may occur in the lower Naust Formation as an effect of underlying polygonal fault reactivation in the Kai Formation caused by abrupt sediment loading, e.g. by glacigenic debris flows (Gay and Berndt, 2007). Figures 2 and 3 demonstrate that the intensity of polygonal faulting decrease eastwards as the thickness of the Kai Formation thins toward the dome crest of the Helland-Hansen Arch. We also note an upward decrease in fault displacement where reflector offsets are absent at the Naust - Kai boundary. This study indicates that where polygonal faults are present in the Kai Formation, subtle deformation and discontinuities may also be present in the lower stratigraphic record of the Naust Formation. This observation is supported by other data from the Vøring Basin (Berndt et al., 2003; and Gay \& Berndt, 2007). Our seismic data also indicate that basal reflectors of the Naust Formation have a wavy reflection configuration. The positive relief correlates with underlying polygonal faults at numerous locations observed on 2D-seismic profiles (Fig. 5), but a detailed evaluation of this statement is difficult due to limited penetration depth of the 3D-seismic data and the coarse 2D-seismic grid.

The fact that Naust unit W reveals a remarkable drop in P-wave velocities throughout the Vøring Basin (Reemst et al., 1996; Hjelstuen et al., 1999; Bünz and Mienert, 2004), poses important implications for the origin of the elongated antiform structure in Naust unit W. Bünz and Mienert (2004) analyzed velocity profiles derived from ocean bottom cable (OBC) seismic data, and indicated that a velocity inversion of an order of magnitude of $\sim 450 \mathrm{~m} \mathrm{~s}^{-1}$ is present in Naust unit W. The OBC profile runs along the 2D-seismic profile shown in Figures 2 and 3, also located within the 3D-seismic data used in this study. Reemst et al. (1996) attributed the current velocity inversion to potentially overpressured formation water trapped below a layer of shale, whilst Bünz and Mienert (2004) suggested free gas as a potential cause. For either reason, i.e. trapped formation water or gassy fluids, Naust unit W has, perhaps, not been able to drain properly to establish pore pressure equilibrium and normal consolidation.

Underconsolidated sediment sequences will show reduced lithostatic gradients, as the sediment density is reduced to less than normal (Maltman and Bolton, 2003). Structural deformation styles facilitated by density inversion and subsequent differential loading have been documented from numerous deep-water sedimentary settings, such as the large-scale (0.5-2 km) hummocks in the Norwegian Basin (Vogt, 1997) and off the coast of United Kingdom (Davies et al., 1999). Density inversions and Rayleigh-Taylor instabilities are mechanisms that have been closely associated with the development of polygonal faults (Henriet et al., 1989), but this is still debated. We suggest that the irregular structure seen on the Naust unit $\mathrm{W}$ relates to similar processes. The elongated antiform structure may have formed in response to a combination of lateral density differences within unit $\mathrm{W}$ and gravitational loading. As a result of local tensile stresses caused by the stretching and bending of layers, fractures or ruptures may propagate parallel to the crest of the antiform (e.g. Ramsay, 1967). The lack of obvious migration pathways from seismic data often leads to the assumption that fluids migrate in a diffusive manner towards the surface, which in most cases, obviously, relates to limitations of seismic imaging. The high-resolution 3D-seismic dataset used in this study facilitates recognition of potential soft-sediment deformation structures that locally may control channeling of fluids towards the GHSZ.

\subsection{Channeling of methane towards the gas hydrate stability zone}

The vertical thickness of the Pleistocene Naust unit R increases up-slope towards the region of greatest glacigenic sedimentation (Fig. 2). It is natural to infer that Naust units $\mathrm{S}$ and $\mathrm{W}$ are exposed to progressively increased compaction rates towards the region of culminated glacigenic sediments, as suggested by Hjelstuen et al. (2004b). Geophysical data analysis (i.e. Hjelstuen et al., 1999; Bünz and Mienert, 2004) supports the idea that sediments of Naust unit 
W may hold trapped gaseous fluids, which are unable to drain along the up-slope dipping beds due to inadequate permeability. Instead, based on numerous seismic observations, we suggest that fluids are able to escape from Naust unit $\mathrm{W}$ by manufacturing self-enhanced permeability. First, the extended columnar zone showing acoustic blanking and randomly allocated bright spots in Naust unit $\mathrm{S}$ lines up immediately above the elongated antiform structure that is located on Top Naust W (Fig. 4c). Second, extraction of instantaneous frequencies at Top Naust W reveals an elongated area showing reduced frequency content compared to background values. It is also intriguing that the low frequency zone correlates to the antiform structure and the overlying, elongated acoustic blanking zone (Fig. 4b). We attribute anomalous low frequencies in this particular region to increased attenuation and absorption of the seismic energy, suggesting that gaseous fluids exist within sediments of the overlying Naust unit S. Third, the elongated columnar zone holds seismic signatures of acoustic blanking, disrupted reflections, and bright reflection segments that terminate instantly below the elongated depression at Top Naust S (Fig. 4c). Summarizing the seismic observations it becomes clear that they are spatially related (Fig. 8), and expose compelling signs for upward focussed fluid flow. A reasonable scenario of the state of fluid migration suggests that fluids escape from the elongate antiform structure, partly due to the positive relief, and partly due to the presence of crest-parallel fissures. Due to increased burial and gravitational load the pore-fluid pressure in sediments of Naust unit W potentially would exceed the minimum confining stress plus the tensile strength, and hydraulically generate fractures that allow fluids to migrate vertically through the $\sim 250 \mathrm{~m}$ thick Naust unit $\mathrm{S}$ (i.e. Hubbert and Willis, 1957; Secor, 1965; Luo and Vasseur, 2002). Elongated seismic blanking zones similar to the seismic signatures shown here have previously been attributed to natural hydraulic fracturing, e.g. Zuhlsdorff and Spiess (2004). As the fluid front advances within hydraulically generated fractures the pore-fluid pressure rapidly decreases below the threshold of least principal stress and some of the fractures are presumed to close (Luo and Vasseur, 2002). However, if the source of overpressure can be maintained the process of fracture generation may be repeated episodically (Roberts and Nunn, 1995). The hydrofractured zone may have played an important role in respect to pressure build-up and pressure discharge in overlying layers as indicated by the cluster of acoustic pipe structures (discussed in section 5.3).

Approximate location of Figure 8.

The channel-like depression that occurs at the Top Naust $S$ and terminates the hydrofractured zone may have three possible origins (Figs. 4, 5 and 8). First, the elongated depression represents a geomorphologic structure caused by bottom water currents formed at a palaeo-seafloor prior to the Elsterian glacial period. The depositional setting in the area, however, does not support down-slope sediment laden bottom-currents. Formation of erosional channels and gullies on continental slopes of formerly glaciated margins is frequently related to melt water processes, a process not known to exist in the current water depth of the study area. Also, it is unlikely that this channel accidentally formed on top of the hydrofractured area.

Second, the elongated depression is another geomorphologic structure, but caused by 'gas turbation'. This is a process similar to individual formation modes of pockmarks, where sediments are either lifted into suspension or prevented to deposit, due to gas or pore water discharge through the seafloor (King and MacLean, 1970). In this case, the elongated depression represents a fossil manifestation of gas and/or pore water discharge into the ocean. According to Hjelstuen et al. (2005) the Top Naust S correlates to marine isotope stage 12 ( $\sim 0.45 \mathrm{Ma})$, i.e. Middle Pleistocene. Hydraulic fracturing probably initiated due to excess pore pressure that relates to increased effective stress caused by high sedimentation rates during Elsterian glaciations, i.e. Naust unit R, marine isotope stage 8-10 (Hjelstuen et al., 
2004a). Accordingly, the elongated fluid conduit (i.e. hydraulic fracturing) in Naust unit S was not established at the time when Top Naust $\mathrm{S}$ formed the seafloor.

Third, the elongated depression observed on the Top Naust $\mathrm{S}$ horizon may correspond to a velocity pseudo-structure, rather than a geomorphological feature (Fig. 4a). Areas of higher gas concentrations compared to adjacent regions may produce longer arrival times for the recorded acoustic signal, commonly referred to as the "push-down" effect. Quantitative modeling of free gas indicates that sediments in the lower section of the Naust unit R (i.e. enhanced reflections) (Fig. 6) hold approximate $1 \%$ of the free gas (Bünz and Mienert, 2004). The instantaneous frequency plot of profile $\mathrm{C}$ in Figure $6 \mathrm{~b}$ demonstrates that the magnitude of frequency loss increases below the elongated depression and the hydraulic fractured zone. We argue that it is most likely due to the overlying layer of free gas. The elongated depression seen at the base of the shallow gas layers (Fig. 8) may represent a zone where gaseous fluids presently are being expelled from the underlying conduit. Hence, the elongated depression is interpreted as a presently active fluid expulsion feature. This interpretation is supported by Berndt et al. (2003; encircled in figure 3, page 285) who described an equivalent depression at the same stratigraphic depth in this area of the northern flank of the Storegga Slide.

\subsection{Acoustic pipes as an indicator for vertical focussed fluid migration}

Vertical zones of acoustic wipe-outs (pipes) have previously been reported from the southern Vøring margin, but the geological processes leading to this seismic signature are far from understood. Several authors (e.g. Baas et al., 1994; Evans et al., 1996; Mienert et al., 1998) suggested that these seismic anomalies were caused by vertical gas and water expulsion, which we unquestionably agree to. Yet, it is still debated whether the upward bending seismic reflections relate to pseudo-velocity structures caused by vertical zones of gas hydrate cementation in the GHSZ and/or precipitation of authigenic carbonates in the near seafloor sediments. Alternatively, the acoustic pipes may correspond to mud diapirs with defined zones of vertically deflected sediment layering due to the confined front of ascending gaseous fluids.

The pipe structures occurring within the 3D-seismic area (P1-P5) terminate at the high amplitude Intra Naust O reflection at approximate 70-80 mbsf, which correlates to the Eemian interglacial period ( 120 ka; Sejrup et al., 2004). As a single pipe may reflect several active periods, we are unable to determine the earliest seep activity. Yet, the timing of the most recent seep activity can be indicated by their upper termination, and involves at least three possible scenarios in the study area, or a combination of them. (1) The pipes were active and pierced the seafloor until the Eemian interglacial period, where seep activity later ceased. (2) The pipe structures are of post-Eemian age, but the excess pore pressure vanished when the pipes reached the stratigraphic level of Intra Naust O. (3) The pipes are of post-Eemian age, but the Intra Naust $\mathrm{O}$ reflector corresponds to a flow barrier that inhibited further advance of the fluid pressure front.

The fact that pockmarks and associated pipe structures are widespread and pierce the present day seafloor (e.g. P6) up-slope of the 3D-seismic area manifest at least one period of relatively high seep activity in post-Eemian times (e.g. Hovland et al., 2005; Mazzini et al., 2006). The geotechnical borehole (6404/5GB1) reveals that sediment properties at 70 mbsf are overconsolidated compared to over-and underlying units (high fraction of clay (41\%), low water content $(38.5 \%)$, low plasticity index $(26.4 \%)$, and high unit weights $\left(18.5 \mathrm{kN} / \mathrm{m}^{3}\right)$ (NGI, 1997). This depth coincides with the upper termination of the pipe structures.

Figure 3 demonstrates how pipe structure P6 pierces the seafloor. The seafloor is not geometrically affected (i.e. by pockmark or mound), but high reflection strength is observed relative to the surrounding areas, suggesting seafloor sediments with different physical properties and a pockmark-scale of subseismic resolution. At seepage sites microbial 
mediated oxidation of methane can lead to carbonate precipitation in the near seafloor sediments (Mazzini et al., 2006), which can produce high acoustic impedance contrasts. Similar to carbonates, gas hydrates have high P-wave velocities (Ecker et al., 1998) and in case they occur near the seafloor one may expect an increasing acoustic impedance contrast. Authigenic carbonates (Mazzini et al., 2005; 2006) and gas hydrates (Ivanov et al., 2007) are recovered from present day seafloor pockmarks in the Nyegga area (Fig. 1). Gas hydrates are chemically unstable at the seafloor due to the low hydrocarbon concentration in the seawater, but also due to the saline seawater (Hovland and Svensen, 2006). Hence, growth of gas hydrates in the near seafloor sediments suggest presently active seepage of dissolved or free gas through the seafloor.

At a regional scale, pipe structure formation is likely controlled by lateral permeability variations in the Naust Formation, corresponding to the massive wedge of glacigenic debris flow up-slope and increased gas hydrate saturation down-slope, which prevents pipe structure development (Fig. 1b). In contrast, the controlling mechanisms for the exact location of pipe formation are less evident at local scales. The location of pipes may be organized by the network of polygonal faults, if they are rooted in the Kai Formation. We certainly agree with Berndt et al. (2003), who indicated that a few pipes originate at depths within the Kai Formation, but more frequent from the high amplitude reflections below the BGHSZ (Fig. 3, 4 and 6). We also note that pipes can originate immediately above triple-junctions of polygonal faults, as demonstrated by observations in the Congo Basin (Gay et al., 2006).

All pipes are located within the northern corner of the 3D-seismic area, in which P1$\mathrm{P} 4$ cluster in the vicinity of the elongated depression at the Top Naust $\mathrm{S}$ reflector. The clustering of pipes is also found adjacent to the elongated hydrofractured zone in Naust unit $S$ where fluids are expelled into the free gas layer below the GHSZ. The elongated depression observed at the Top Naust S horizon may relate to a pseudo-velocity structure, a push-down (i.e. longer arrival times due to anomalous low P-wave velocities compared to background velocities). Hence, the push-down suggests a presently active fluid expulsion feature, which may have periodically contributed to excess pore-fluid pressure sufficient to trigger pipe structure formation.

\subsection{Conceptual fluid flow model}

Based on observations from the high-resolution 3D-seismic data we have developed a conceptual model demonstrating the spatial connection between geomorphological structures and seismic signatures, which interacts with focussed fluid migration (Fig. 9). The model is widely applicable for the entire northern flank of the Storegga Slide, as well as other glaciated continental margins in similar depositional settings. (1) The elongated antiform in Naust unit $\mathrm{W}$ formed in response to density differences, differential loading and underlying polygonal faulting. (2) Naust unit $\mathrm{W}$ is an overpressured unit, where the pore-fluid pressure front reaches the least principal stress and fluids escape from the overpressured unit by initiating or self-enhancing fractures. A high pore-fluid pressure can be maintained by volume expansion of the ascending gas as the fractures propagate. Hydraulically generated fractures may therefore occur vertically through several hundred meters of sediments until the fluid pressure front enters layers of higher permeability and porosity. (3) Pseudo-velocity structures, i.e. push-downs, point towards a higher concentration of gaseous fluids compared to surrounding strata. Fluids are expelled into a layer with slightly higher porosity and permeability where free gas is trapped beneath gas-hydrated sediments down-slope. As shown, a "push-down" can form at the site where gaseous fluids are expelled from underlying hydraulically fractured sediments. (4) Acoustic pipes cluster in areas with the highest gas concentration (i.e. elongated push-down) representing a "geological pressure valve" in periods of excess porefluid pressure build-up. (5) High impedance contrast on top of individual pipe structures 
indicates precipitation of authigenic carbonates and/or gas hydrates near the seafloor, suggesting that the pipes are (micro-scale) conduits for long term methane seepage.

Approximate location of Figure 9.

\section{CONCLUSIONS}

i) High-resolution 3D-seismic data reveals details of conduits that feed methane and pore-water from the base of the Naust Formation towards the gas hydrate stability zone at the northern flank of the Storegga Slide.

ii) Low relief antiform structures form in the basal unit of the Naust Formation, unit $\mathrm{W}$, with comparable height-to-width aspect ratio. These soft-sediment deformation structures provide hints to processes also discussed for the onset of polygonal faulting, e.g. density inversion and differential loading. Potentially, these antiforms can be pre-stage polygonal faults or reactivation of deeper polygonal faults in the Kai Formation.

iii) Fractures and ruptures are formed along the crests of the elongated antiform structures. They constitute preferred locations where pore-fluid pressure exceeds the minimum confining stress and tensile strength of the hosting sediment. As a consequence, gaseous fluids escape the overpressured Naust unit W by manufacturing self-enhanced permeability, i.e. hydraulic generation of fractures. Hydraulic fracturing occurs vertically for approximate $250 \mathrm{~m}$ until the fluid front arrives at beds of slightly higher permeability and porosity below the gas hydrate stability zone in Naust unit R.

iv) Confined zones of acoustic push-downs located immediately above hydraulic fractured regions are indicators of appreciable free-gas concentrations. Higher gas concentrations trigger elevated pore-fluid pressures in restricted areas, explaining why acoustic pipe structures cluster in confined areas.

v) The timing of the fluid flow related geological structures is uncertain, but they are likely triggered by high sedimentation rates and rapid changes from glacial to interglacial times.

vi) Each of the individual structures and acoustic signatures described are not always stand-alone indicators for channeling of fluids. Yet, their spatial relationship reveals compelling signs for focussed fluid flow enabling discrimination of the respective processes under which they are formed.

\section{ACKNOWLEDGEMENTS}

The University of Troms $\varnothing$ acknowledges support by GeoQuest for seismic interpretation software and support, and Ståle Schwenke for keeping the GeoQuest software running. The GMT software (Wessel \& Smith, 1991) was used to create the maps in Figure 1. Acquisition of the high-resolution 3D-seismic data was carried out by IFREMER in context with the EU-funded HYDRATECH project contract, while the seismic visualization work has been financed by the NFR (Norwegian Research Council) under the PETROMAKS-project 169514/S30. The authors acknowledge reviews by Prof. Joe Cartwright and one anonymous reviewer. Their helpful comments improved an earlier version of the manuscript.

\section{REFERENCES}

Baas, J.H., Mienert, J., Schultheiss, P., Evans, D., 1994. Evidence of gas vents and gas hydrates in the storegga slide area (Norwegian Continental Margin), 3rd International Conference, NIOZ, Texel, The Netherlands.

Berndt, C., 2005. Focused fluid flow in passive continental margins. Phil. Trans. R. Soc. A, 363: 2855-2871.

Berndt, C., Bünz, S., Mienert, J., 2003. Polygonal fault systems on the Mid-Norwegian margin: a long-term source for fluid flow. In: P.V. Rensbergen, R. Hillis, A. Maltman 
and C. Morley (Editors), Origin, Processes, and Effects of Subsurface Sediment

Mobilization on reservoir to regional scale. Geological Society of London, Special Publication.

Bouriak, S., Vanneste, M., Saoutkine, A., 2000. Inferred gas hydrates and clay diapirs near the Storegga Slide on the southern edge of the Vøring Plateau, offshore Norway. Marine Geology, 163: 125-148.

Brekke, H., 2000. The tectonic evolution of the Norwegian Sea continental margin with emphasis on the Vøring and Møre Basins. Dynamics of the Norwegian Margin. A. Nøttvedt. London, Geological Society of London, Special Publication, 167: 327-378.

Brekke, H., Riis, F., 1987. Tectonics and evolution of the Norwegian shelf between 62 degrees N and 72 degrees N. Norsk Geol. Tidsskr., 67: 295-321.

Bryn, P., Østmo, S.R., Lien, R., Berg, K., Tjelta, T.I., 1998. Slope stability in the deep water areas off Mid-Norway, Offshore Technology Conference, Houston, Texas.

Bugge, T., Belderson, R.H., Kenyon, N.H., 1988. The Storegga Slide. Philosophical Transactions of the Royal Society of London, A 325: 357-388.

Bünz, S., Mienert, J., 2004. Acoustic imaging of gas hydrate and free gas at the Storegga Slide. J. Geophys. Res., 109.

Bünz, S., Mienert, J., Berndt, C., 2003. Geological controls on the Storegga gas-hydrate system of the mid-Norwegian continental margin. Earth and Planetary Science Letters, 209(3-4): 291-307.

Bünz, S., Mienert, J., Bryn, P., Berg, K., 2005. Fluid flow impact on slope failure from threedimensional seismic data: a case study in the Storegga Slide. Basin Research, 17: 109122.

Cartwright, J.A., Lonergan, L., 1996. Volumetric contraction during the compaction of mud rocks: a mechanism for the development of regional-scale polygonal fault system. Basin Research, 8: 183-193.

Cartwright, J.A., Dewhurst, D.N., 1998. Layer-bound compaction faults in fine-grained sediments. Geological Society of America Bulletin, 110(10): 1242-1257.

Dalland, A., Worsley, D., Ofstad, K., 1988. A lithostratigraphic scheme for the Mesoxoic and Cenozoic succession offshore mid- and northern Norway. Norwegian Peetroleum Directorate, NPD-Bulletin 4, Stavanger., Norway.

Davies, R., Cartwright, J.A., Rana, J., 1999. Giant hummocks in deep-water marine sediments; evidence for large-scale differential compaction and density inversion during early burial. Geology, 27(10): 907-910.

Dimitrov, L.I., 2002. Mud volcanoes--the most important pathway for degassing deeply buried sediments. Earth-Science Reviews, 59(1-4): 49-76.

Doré, A.G., Lundin, E.R., 1996. Cenozoic compressional structures on the NE Atlantic margin: nature, origin and potential significance for hydrocarbon exploration. Petroleum Geosciences, 2: 299-311.

Ecker, C., Dvorkin, J., Nur, A., 1998. Sediments with gas hydrates: internal structure from seismic AVO. Geophysics 63, 5: 1659-1669.

Evans, D., King, E.L., Kenyon, N.H., Brett, C., Wallis, D., 1996. Evidence for long-term instability in the Storegga Slide region off Western Norway. Marine Geology, 130: 281-292.

Gay, A., Berndt, C., 2007. Cessation/reactivation of polygonal faulting and effects on fluid flow in the Voring Basin, Norwegian Margin. Journal of the Geological Society, 164(1): 129-141.

Gay, A., Lopez, M., Cochonat, P., Seranne, M., Levache, D., Sermondadaz, G., 2006. Isolated seafloor pockmarks linked to BSRs, fluid chimneys, polygonal faults and stacked 
Oligocene-Miocene turbiditic palaeochannels in the Lower Congo Basin. Marine Geology, 226(1-2): 25-40.

Goulty, N.R., Swarbrick, R.E., 2005. Development of polygonal fault systems: a test of hypotheses. Journal of Geological Society, 162: 587-590.

Henriet, J.P., De Batist, M., Verschuren, M., 1989. Seismic facies and clay tectonic features in the Southern North Sea. Bulletin of the Belgian Geological Society, 97: 457-472.

Hjelstuen, B.O., Eldholm, O., Skogseid, J., 1997. Vøring Plateau diapir fields and their structural and depositional settings. Marine Geology, 144: 33-57.

Hjelstuen, B.O., Eldholm, O., Skogseid, J., 1999. Cenozoic evolution of the northern Vøring margin. Geological Society of America Bulletin, 111(12): 1792-1807.

Hjelstuen, B.O., Sejrup, H.P., Haflidason, H., Nygaard, A., Berstad, I.M., Knorr, G., 2004a. Late Quaternary seismic stratigraphy and geological development of the south Vøring margin, Norwegian Sea. Quaternary Science Reviews, 23(16-17): 1847-1865.

Hjelstuen, B.O., Sejrup, H.P., Haflidason, H., Berg, K., Bryn, P., 2004b. Neogene and Quaternary depositional environments on the Norwegian continental margin, 62[deg]N-68[deg]N. Marine Geology, 213(1-4): 257-276.

Hjelstuen, B.O., Petter Sejrup, H., Haflidason, H., Nygard, A., Ceramicola, S., Bryn, P., 2005. Late Cenozoic glacial history and evolution of the Storegga Slide area and adjacent slide flank regions, Norwegian continental margin. Marine and Petroleum Geology, 22(1-2): 57-69.

Holbrook, S.W., Hoskins, H., Wood, W.T., Stephen, R.A., Lizzarralde, D., Party, L.S., 1996. Methane gas-hydrate and free gas on the Blake Ridge from vertical seismic profiling. Science, 273: 1840-1843.

Hovland, M., Judd, A.G., 1988. Seabed pockmarks and seepages: impact on geology, biology and the marine environment. Graham \& Trotman Ltd., London, $293 \mathrm{pp}$.

Hovland, M., Svensen, H., 2006. Submarine pingoes: Indicators of shallow gas hydrates in a pockmark at Nyegga, Norwegian Sea. Marine Geology, 228(1-4): 15-23.

Hovland, M., Svensen, H., Forsberg, C.F., Johansen, H., Fichler, C., Fossa, J.H., Jonsson, R., Rueslatten, H., 2005. Complex pockmarks with carbonate-ridges off mid-Norway: Products of sediment degassing. Marine Geology, 218(1-4): 191-206.

Hubbert, M.K., Willis, D.G.W., 1957. Mechanics of hydraulic fracturing. Trans. Am. Inst. Min. Eng., 210: 153-168.

Ivanov, M., Blinova, V., Kozlova, E., Westbrook, G.K., Mazzini, A., Nouzé, H., Minshull, T.A., 2007. First sampling of gas hydrate from the Vøring Plateau. EOS, 88(19).

King, L.H., MacLean, B., 1970. Pockmarks on the Scotian Shelf. Geol. Soc. Am. Bull., 81: 3141-3148.

Kvenvolden, K.A., 1993a. Gas hydrates: geological perspective and global change. Review of Geophysics, 31(2): 173-187.

Kvenvolden, K.A., 1993b. Worldwide distribution of subaquatic gas hydrates. Geo-Marine Letters, 13: 32-40.

Luo, X., Vasseur, G., 2002. Natural hydraulic cracking: numerical model and sensitivity study. Earth and Planetary Science Letters, 201(2): 431-446.

Løseth, H., Wensaas, L., Arntsen, B., Hanken, N., Basire, C., Graue, K., 2001. 1000 m long blow-out pipes, EAGE 63rd Conference \& Technical Exibition, 11-15 June, Amsterdam, Netherlands.

Maltman, A.J., Bolton, A., 2003. How sediments become mobilized. Geological Society, London, Special Publications, 216(1): 9-20.

Mazzini, A., Jonk, R., Duranti, D., Parnell, J., Cronin, B., Hurst, A., 2003. Fluid escape from reservoirs: implications from cold seeps, fractures and injected sands. Part I. The fluid flow system. Journal of Geochemical Exploration, 78-79: 293-296. 
Mazzini, A., Aloisi, G., Akhmanov, G.G., Parnell, J., Cronin, B.T., Murphy, P., 2005. Integrated petrographic and geochemical record of hydrocarbon seepage on the Voring Plateau. Journal of the Geological Society, 162(5): 815-827.

Mazzini, A., Svensen, H., Hovland, M., Planke, S., 2006. Comparison and implications from strikingly different authigenic carbonates in a Nyegga complex pockmark, G11, Norwegian Sea. Marine Geology, 231(1-4): 89-102.

Mienert, J., Posewang, J., Baumann, M., 1998. Gas hydrates along the north-eastern Atlantic Margin: possible hydrate bound margin instabilities and possible release of methane. In: J.-P. Henriet and J. Mienert (Editors), Gas Hydrates: Relevance to World Margin Stability and Climatic Change. Geological Society of London, Special Publication, pp. 275-291.

Mienert, J., Posewang, J., Lukas, D., 2001. Changes in the Hydrate Stability Zone on the Norwegian Margin and their Consequences for Methane and Carbon Releases into the Oceanosphere. In: P. Schlaefer, W. Ritzrau, W. Schlueter and J. Thiede (Editors), The Northern North Atlantic: A Changing Environment. Springer, Berlin, pp. 259-280.

Mienert, J., Vanneste, M., Bünz, S., Andreassen, K., Haflidason, H., Sejrup, H.P., 2005. Ocean warming and gas hydrate stability on the mid-Norwegian margin at the Storegga Slide. Marine and Petroleum Geology, 22: 233-244.

Milkov, A.V., Claypool, G., Lee, Y.-J., Torres, M.E., Borowski, W.S., Tomaru, H., Sassen, R., 2004. Ethane enrichment and propane depletion in subsurface gases indicate gas hydrate occurrence in marine sediments at southern Hydrate Ridge offshore Oregon. Organic Geochemistry, 35: 1067-1080.

NGI, 1997. Møre and Vøring Soil Investigations 1997. Report number 972521-1, Norwegian Geotechnical Institute.

Nimblett, J., Ruppel, C.D., 2003. Permeability evolution during the formation of gas hydrates in marine sediments. Journal of Geophysical Research, 108(B9): 2420, doi:10.1029/2001JB001650.

Nouzé, H., Contrucci, I., Foucher, J.P., Marsset, B., Thomas, Y., Thereau, E., Normand, A., Le Drezen, E., Didailler, S., Régnault, J.P., Le Conte, S., Guidart, S., Lekens, W., Dean, S., Throo, A., 2004. Premiers résultats d'une étude géophysique sur le flanc nord des glissements de Storegga (Norvège). Comptes Rendus Géosciences, 336: 1181-1189.

Ramsay, J.G., 1967. Folding and Fracturing of Rocks. McGraw-Hill, New York, 568 pp.

Reemst, P.J., Skogseid, J., Larsen, B.T., 1996. Base Pliocene velocity inversion on the eastern Vøring Margin - Causes and implications. Global Planet. Change, 12: 201-211.

Rise, L., Ottesen, D., Berg, K., Lundin, E., 2005. Large-scale development of the midNorwegian margin during the last 3 million years. Marine and Petroleum Geology, 22(1-2): 33-44.

Roberts, S.J., Nunn, J.A., 1995. Episodic fluid expulsion from geopressured sediments. Marine and Petroleum Geology, 12(2): 195-202.

Rokoengen, K., Rise, L., Bryn, P., Frenstad, B., Gustavsen, B., Nygaard, E., Sættem, J., 1995. Upper Cenozoic stratigraphy on the mid-Norwegian continental shelf. Norsk Geologisk Tidsskrift, 75(2-3): 88-104.

Secor, D.T., 1965. Role of fluid pressure in jointing. American Journal of Science, 263: 633646.

Sejrup, H.P., Haflidason, H., Hjelstuen, B.O., Nygaard, A., Bryn, P., Lien, R., 2004. Pleistocene development of the SE Nordic Seas margin. Mar. Geol., 213: 169-200.

Shipley, T.H., Houston, M.K., Buffler, R.T., Shaub, F.J., McMillan, K.J., Ladd, J.W., Worzel, J.L., 1979. Seismic reflection evidence for the widespread occurrence of possible gas 
hydrate horizons on continental slopes and rises. American Association of Petroleum Geologists, Bulletin, 63: 2201-2213.

Skogseid, J., Pedersen, T., Eldholm, O., Larsen, B.T., 1992. Tectonism and magmatism during NE Atlantic continental break-up: the Vøring Margin. Geol. Spec.Publ., 68: 305-320.

Sloan, E.D.J., 1998. Clathrate Hydrates of Natural Gases. Marcel Dekker Inc., New York \& Basel, 705 pp.

Solheim, A., Bryn, P., Sejrup, H.P., Mienert, J., Berg, K., 2005a. Ormen Lange--an integrated study for the safe development of a deep-water gas field within the Storegga Slide Complex, NE Atlantic continental margin; executive summary. Marine and Petroleum Geology, 22(1-2): 1-9.

Solheim, A., Berg, K., Forsberg, C.F., Bryn, P., 2005b. The Storegga Slide complex: repetitive large scale sliding with similar cause and development. Marine and Petroleum Geology, 22(1-2): 97-107.

Suess, E., Torres, M.E., Bohrmann, G., Collier, R.W., Greinert, J., Linke, P., Rehder, G., Trehu, A., Wallmann, K., Winckler, G., Zuleger, E., 1999. Gas hydrate destabilization: enhanced dewatering, benthic material turnover and large methane plumes at the Cascadia convergent margin. Earth and Planetary Science Letters, 170(1-2): 1-15.

Svensen, H., Planke, S., Malthe-Sørenssen, A., Jamtveit, B., Myklebust, R., Rasmussen Eidem, T., Rey, S.S., 2004. Release of methane from a volcanic basin as a mechanism for initial Eocene global warming. Nature, 429: 542-545.

Taner, M.t., Koehler, F., Sheriff, R.E., 1979. Complex trace analysis. Geophysics, 44(6): 1041-1063.

Thomas, Y., Marsset, B., Didailler, S., Régnault, J.P., Le Conte, S., Le Roux, D., Farcy, P., Magueur, M., Viollette, P., Hervéou, J., Guedes, J.C., Jégot, B., Gascon, G., Prud'homme, C., Nouzé, H., Thereau, E., Contrucci, I., Foucher, J.P., 2004. Sismique marine haute résolution 3D: un nouvel outil de reconnaissance à destination de la communauté scientifique. Comptes Rendus Géosciences, 336: 579-585.

Vogt, P.R., 1997. Hummock fields in the Norway Basin and Eastern Iceland Plateau: Rayleigh-Taylor instabilities? Geology, 25(6): 531-534.

Vogt, P.R., Yung, W.-Y., 2002. Holocene mass wasting on upper non-Polar continental slopes - due to post-glacial ocean warming and hydrate dissociation? Geophysical Research Letters, 29(9).

Vågnes, E., Gabrielsen, R.H., Haremo, P., 1998. Late Cretaceous - Cenozoic intraplate contractional deformation at the Norwegian continental shelf: timing, magnitude and regional implications. Tectonophysics, 300(29-46).

Yilmaz, O., 1987. Seismic data processing: Investigation in Geophysics, 2. Society of Exploration Geophysicists, Tulsa, 526 pp.

Zuhlsdorff, L., Spiess, V., 2004. Three-dimensional seismic characterization of a venting site reveals compelling indications of natural hydraulic fracturing. Geology, 32(2): 101104. 
TABLE

750

Hydratech 3D

P1

P2

P3

P4

P5

Diameter

$130 \mathrm{~m}$

$80 \mathrm{~m}$

$120 \mathrm{~m}$

$100 \mathrm{~m}$

$110 \mathrm{~m}$

Square measure $\left(\mathbf{m}^{2}\right)$

$12230 \mathrm{~m}^{2}$

$5125 \mathrm{~m}^{2}$

$10675 \mathrm{~m}^{2}$

$7195 \mathrm{~m}^{2}$

$10095 \mathrm{~m}^{2}$

Upper termination

Int Naust O

Int Naust O

Int Naust O

Int Naust O

Int Naust $\mathrm{O}$

Acoustic signature

Pull-up

Pull-up

Pull-up

Pull-up

Pull-up

Magnitude of pull-up

$8 \mathrm{~ms}$

$4 \mathrm{~ms}$

$4 \mathrm{~ms}$

$4 \mathrm{~ms}$

$4 \mathrm{~ms}$

Seabed phenomenon

None

None

None

None

None

751

$\begin{array}{llllr}\text { NH9651-202 } & \text { P6 } & \text { P7 } & \text { P8 } & 752 \\ \text { Width } & 130 \mathrm{~m} & 60 \mathrm{~m} & 130 \mathrm{~m} & 753 \\ \text { Upper termination } & \text { Seafloor } & \text { Int Naust O } & \text { Int Naust } 755 \\ \text { Acoustic signature } & \text { Pull-up } & \text { Pull-up } & \text { Pull-up756 } \\ \text { Magnitude pull-up } & 8 \mathrm{~ms} & 6 \mathrm{~ms} & 5 \mathrm{~ms} & 757 \\ \text { Seabed phenomenon } & \text { High reflectivity } & \text { None } & \text { None } & 758 \\ 759\end{array}$

Table 1: A schematic expression of the acoustic pipe structures within the high-resolution 3D-seismic dataset and the 2D-seismic profile NH9651-202A. Int Naust $\mathrm{O}=$ Intra Naust $\mathrm{O}$ reflection. 

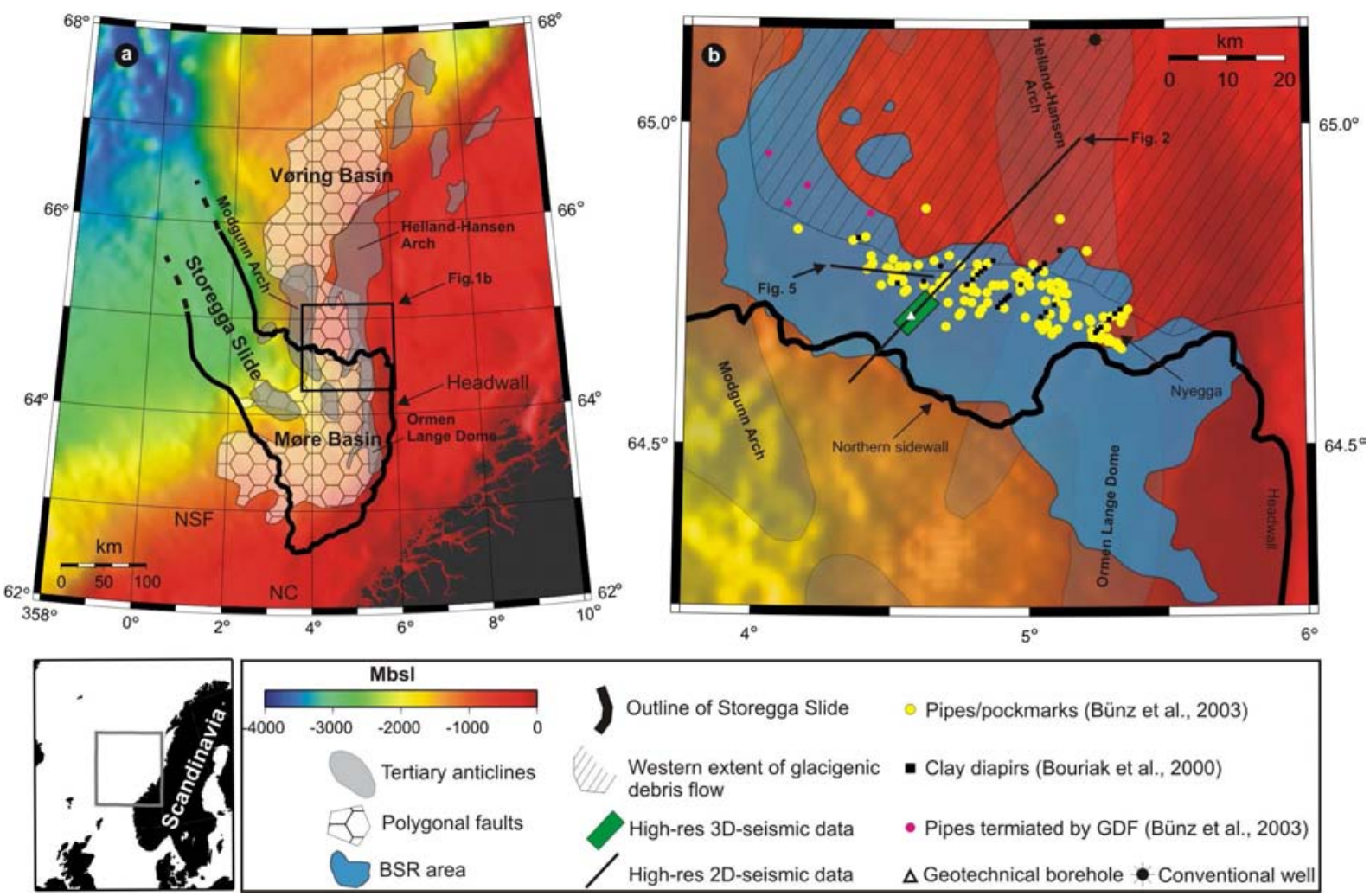

Outline of Storegga Slide

- Pipes/pockmarks (Bünz et al., 2003)

Western extent of glacigenic debris flow

High-res 3D-seismic data

- Clay diapirs (Bouriak et al., 2000)

- Pipes termiated by GDF (Bünz et al., 2003)

Figure 1: Shaded relief map showing the study area at the northern flank of the Storegga Slide of the midNorwegian margin. Important elements located in the Vøring and Møre Basins are the Tertiary anticlines, polygonal faults, Storegga Slide complex, and the variety of fluid escape features. The North Sea Fan (NSF) and Norwegian channel (NC) are indicated. Location of 2D- and 3D-seismic data that is used in this study is shown. 


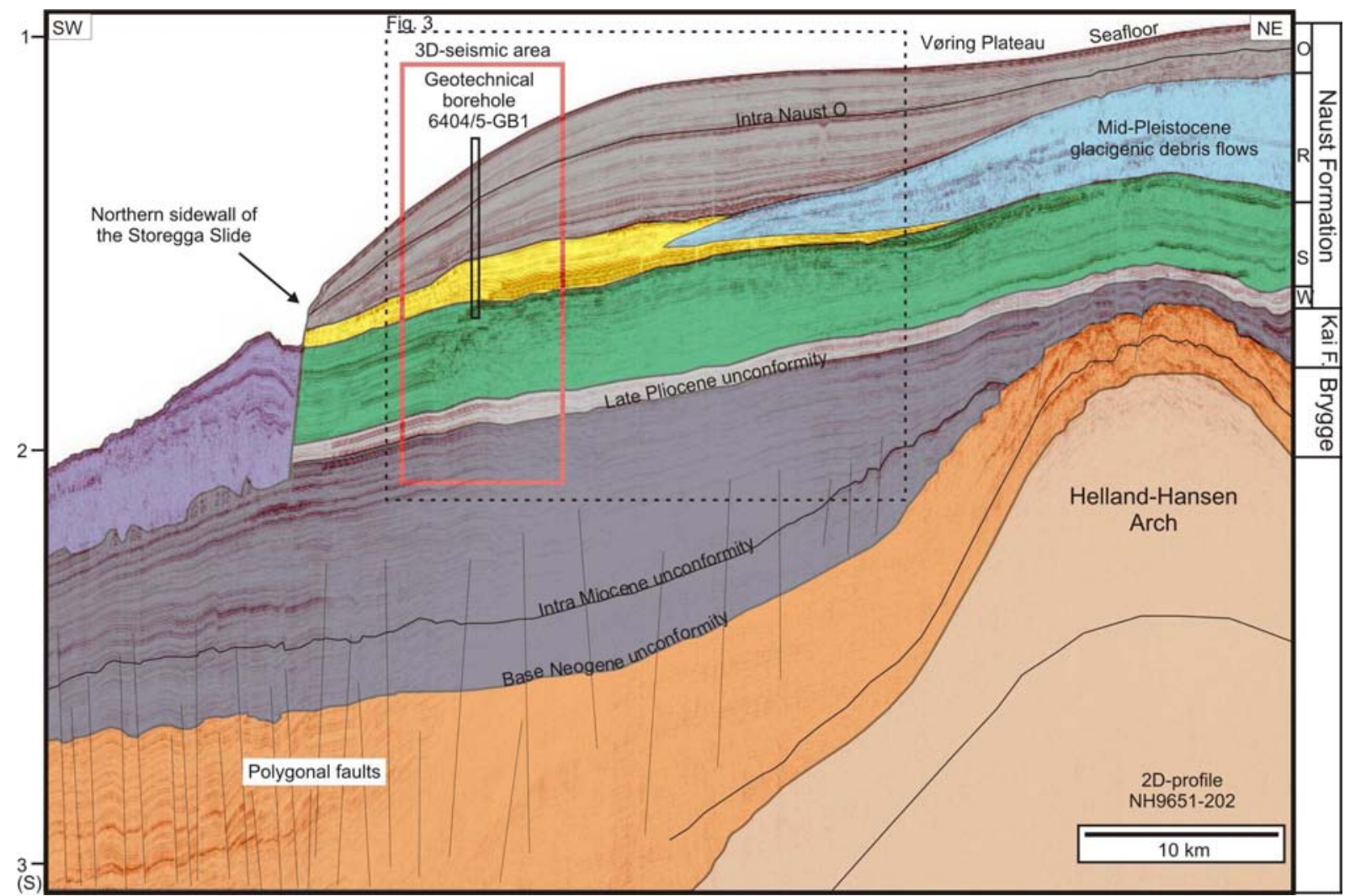

Figure 2: The SW-NE oriented seismic cross-section showing the regional geologic features and the stratigraphic units in the southern Vøring Basin (Fig. 1). This study mainly encompasses fluid flow features from the upper section of the Kai Formation to the seafloor. The red rectangle indicates the location of the high-resolution 3D-seismic area. A geotechnical borehole is positioned within the 3Dseismic area. Location of the seismic data is shown in Figure 1. 


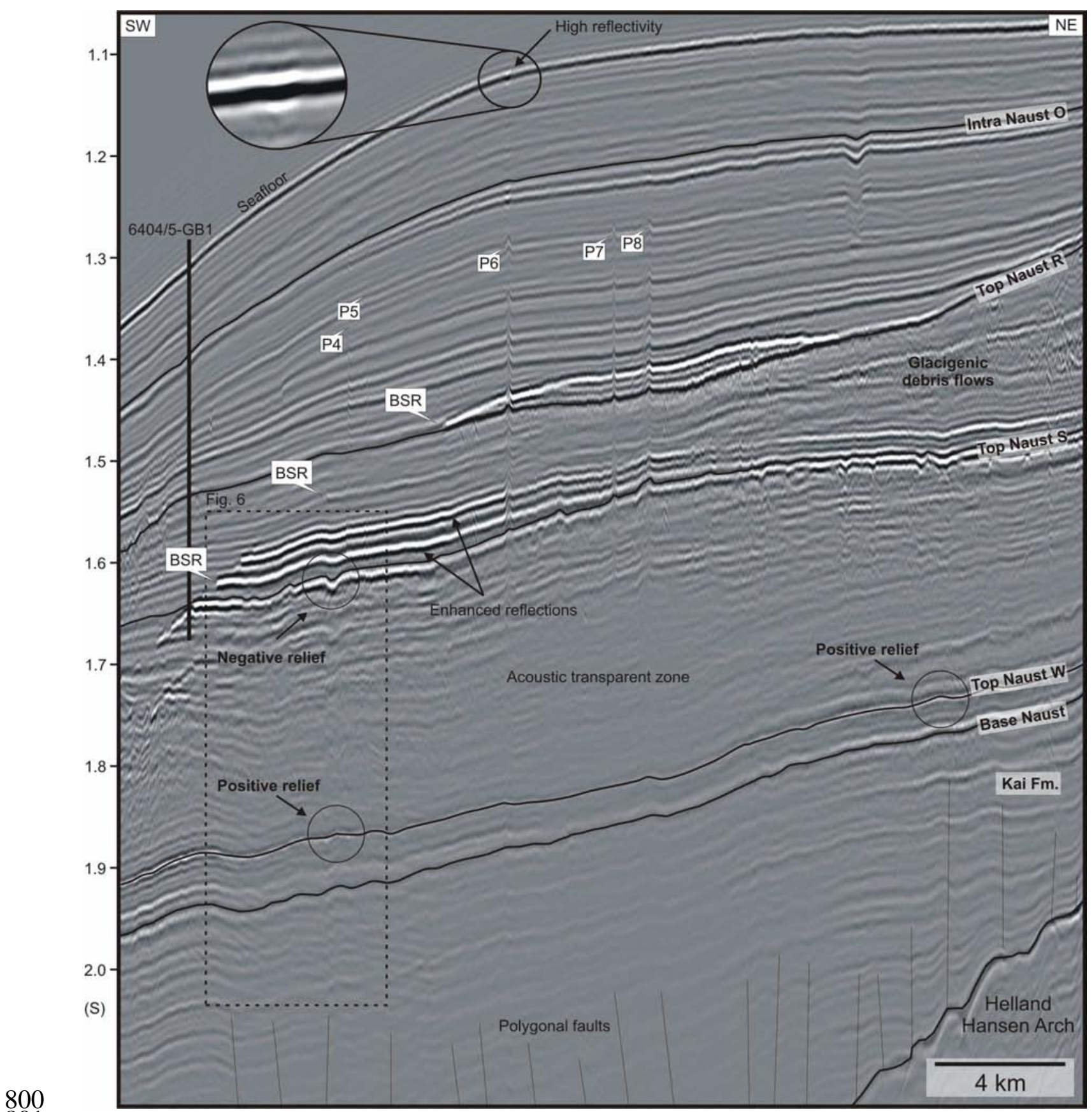

Figure 3: The regional 2D-seismic cross-section indicates the presence of acoustic pipes (Pn), enhanced 803 reflections, a gas-hydrate related BSR, and a wedge of glacigenic debris flows deposited from the NE. Note the relatively high reflectivity at the seafloor above P6. The dotted rectangle indicates the position of 804 Figure 4. See Figure 2 for location of seismic profile. 


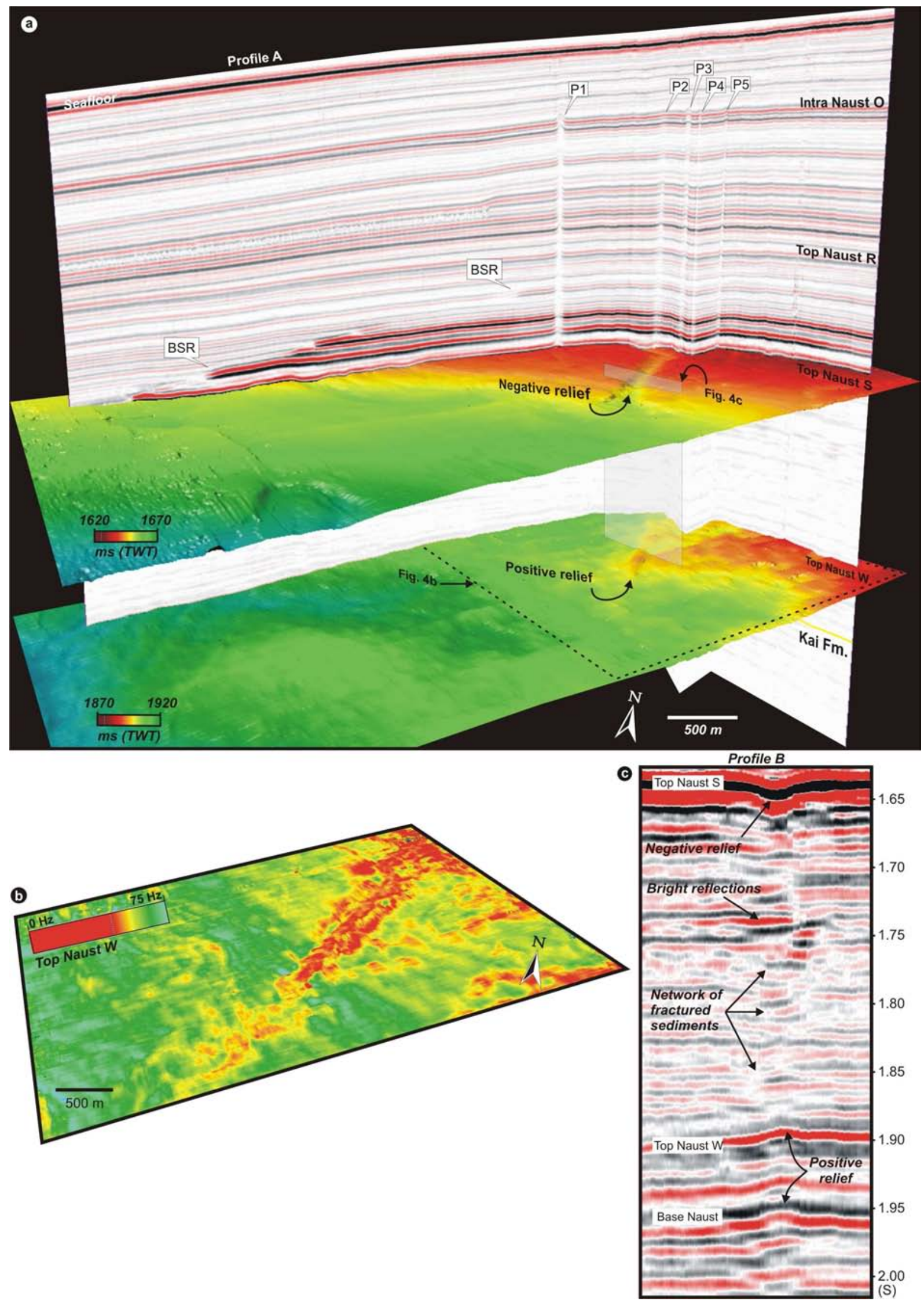

Figure 4: A) Perspective view showing shaded relief maps of the two key horizons Top Naust $W$ and Top Naust $\mathbf{S}$, intersected by the 'random' seismic profile A. Vertical exaggeration is 4 , and location of profile A

809 is shown in Figure 6. The elongated positive relief (i.e. antiform structure) completely underlies the elongated negative relief (i.e. possible push-down) located on the grids of the Top Naust W and S, 
811

812

813

814

815

816

817

818

respectively. B) Perspective view of the instantaneous frequency map of the Top Naust $W$ designates that anomalous low frequencies concentrate immediately below the area containing potential fractured sediments. Map position is indicated in Figure 4a. C) Seismic profile B demonstrates the columnar zone showing acoustic turbidity, bright spots and lateral reflection discontinuities interpreted to be fractured sediments, providing an obvious link between the underlying antiform structure and the overlying pushdown. See Figure 6 for location of seismic section.

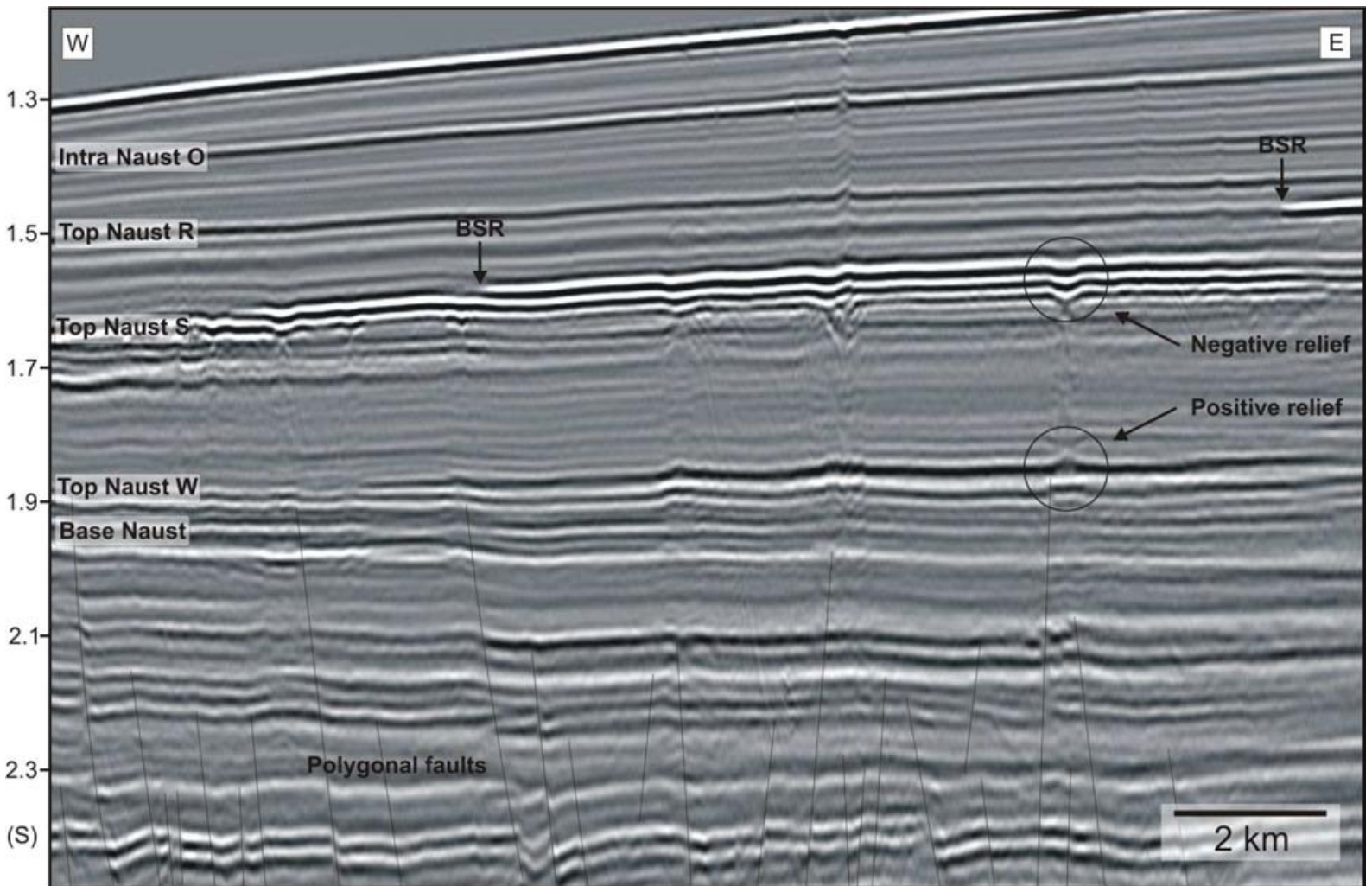

Figure 5: The 2D-seismic line is running E-W $3 \mathrm{~km}$ north of the 3D-seismic dataset, and demonstrates that polygonal faults extend into the basal unit of the Naust Formation. Also, positive relief structures commonly occur where polygonal faults deform Naust Formation sediments, or reach close to Naust-Kai Formation boundary. See Figure 1 for location of seismic line.

Profile C

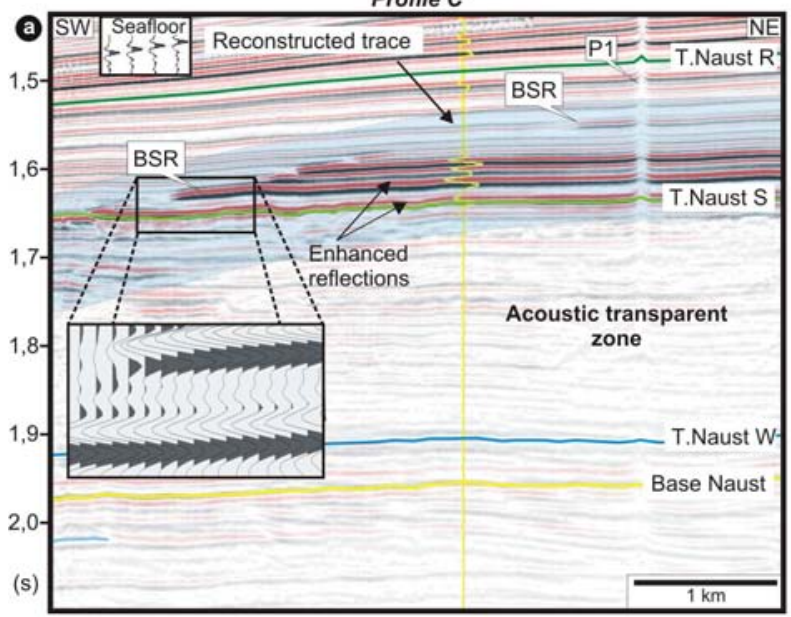

Profile C

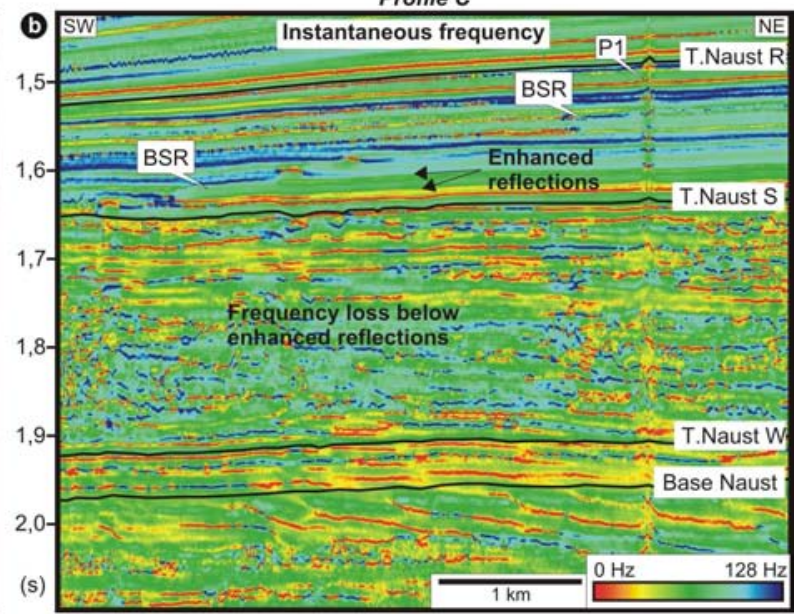

Figure 6: A) The seismic cross-section shows the BSR, enhanced reflections caused by the free gas, and the underlying transparent zone. The wa-viggle display demonstrates the phase reversal across the BSR. B) The seismic attribute Instantaneous Frequency is calculated from the seismic cross-section in A, and demonstrates a remarkable decrease in dominant frequencies below the free gas in the lower section of Naust unit R. See Figure 6 for location of the seismic cross-section (Inline part of profile A). 


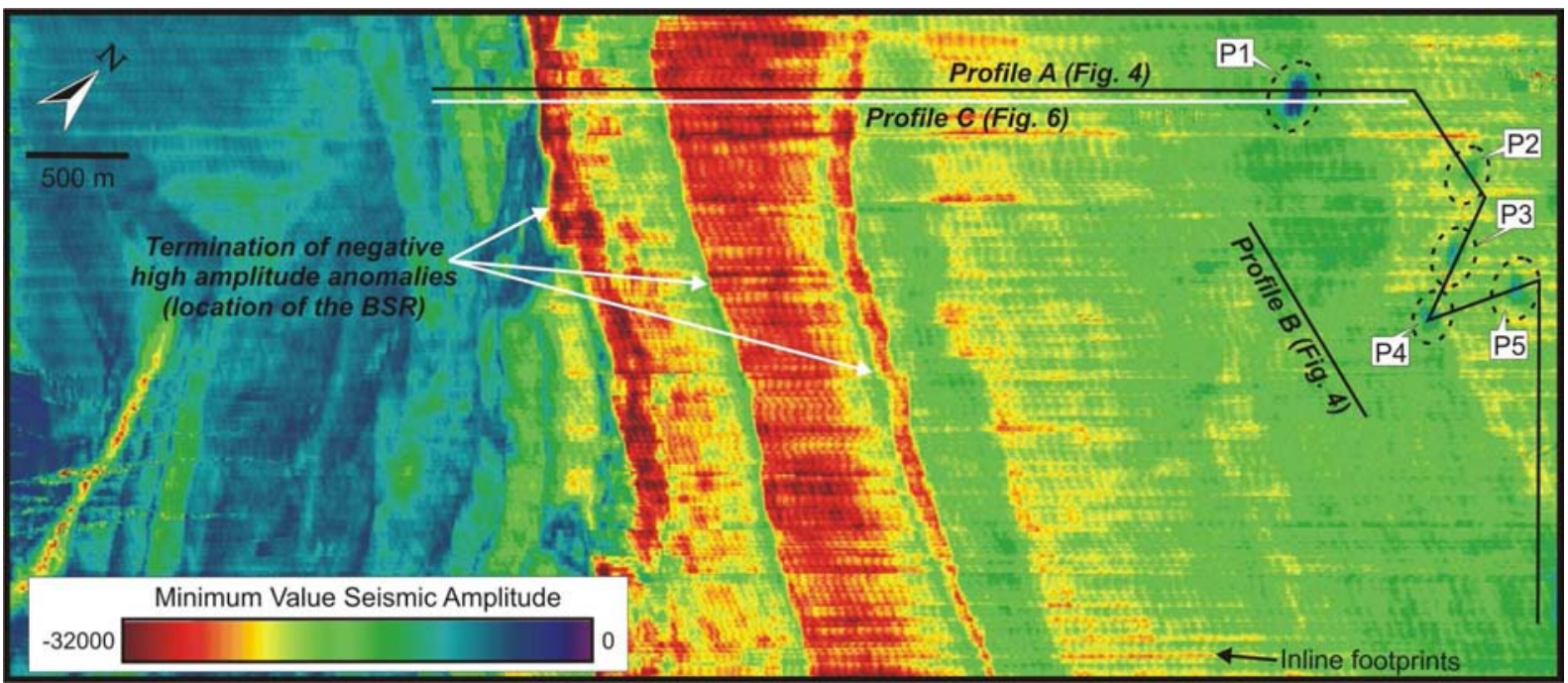

Figure 7: The volume based attribute map images the distribution of the Minimum Seismic Amplitudes, calculated from a $100 \mathrm{~ms}$ interval (blue shaded volume in Figure 5a). Note the cluster of ellipsoidal shaped amplitude wipe-outs (encircled) in the northern corner of the 3D-seismic area, but also how their

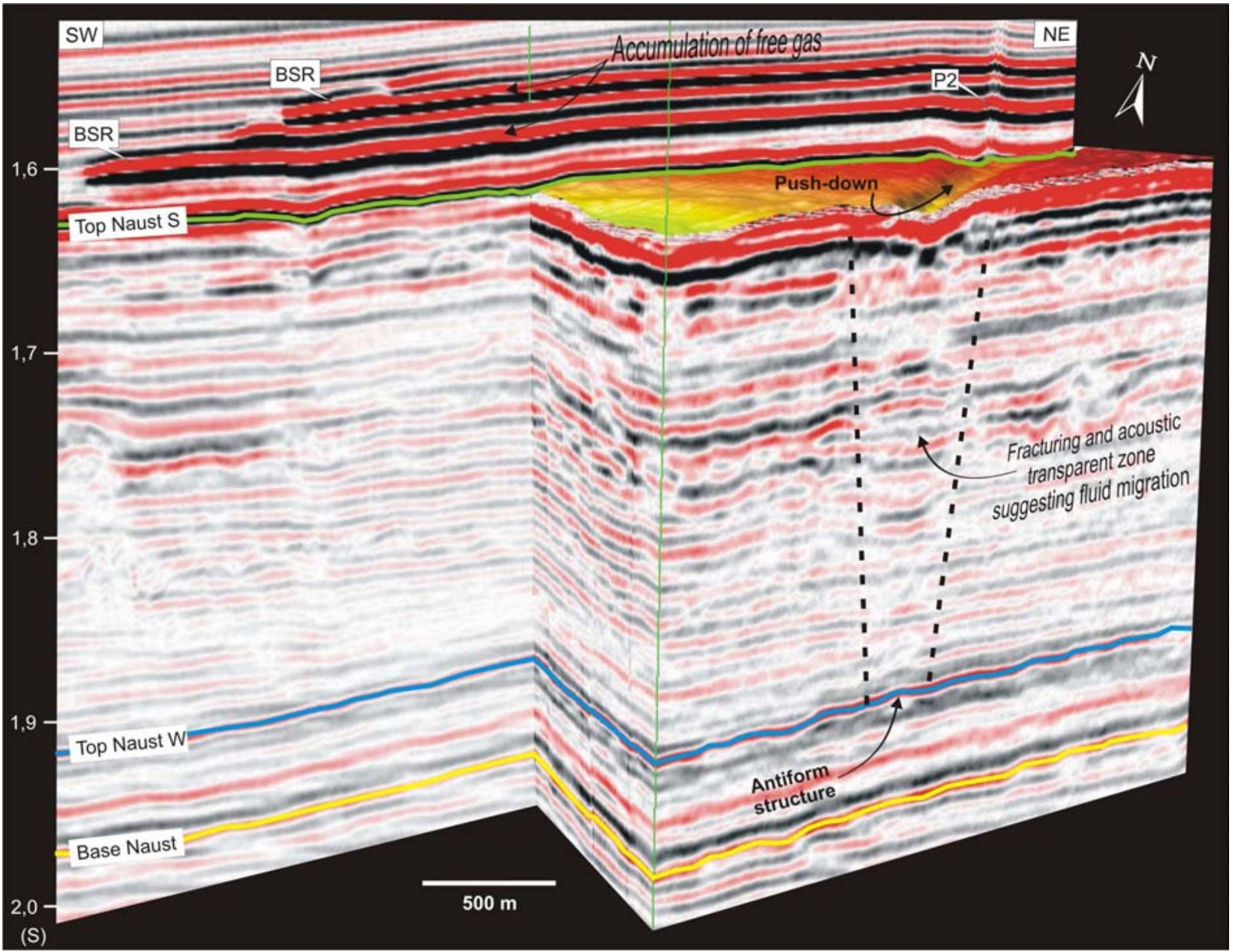
S

Figure 8: Perspective view of an inline cross-section, a cropped seismic cube, and the shaded relief map of Top Naust S. The figure displays unambiguous relationships between various structures located at different stratigraphic depths, suggesting they are all associated with focussed fluid migration. View-point is from SSW and the vertical exaggeration is 6. 


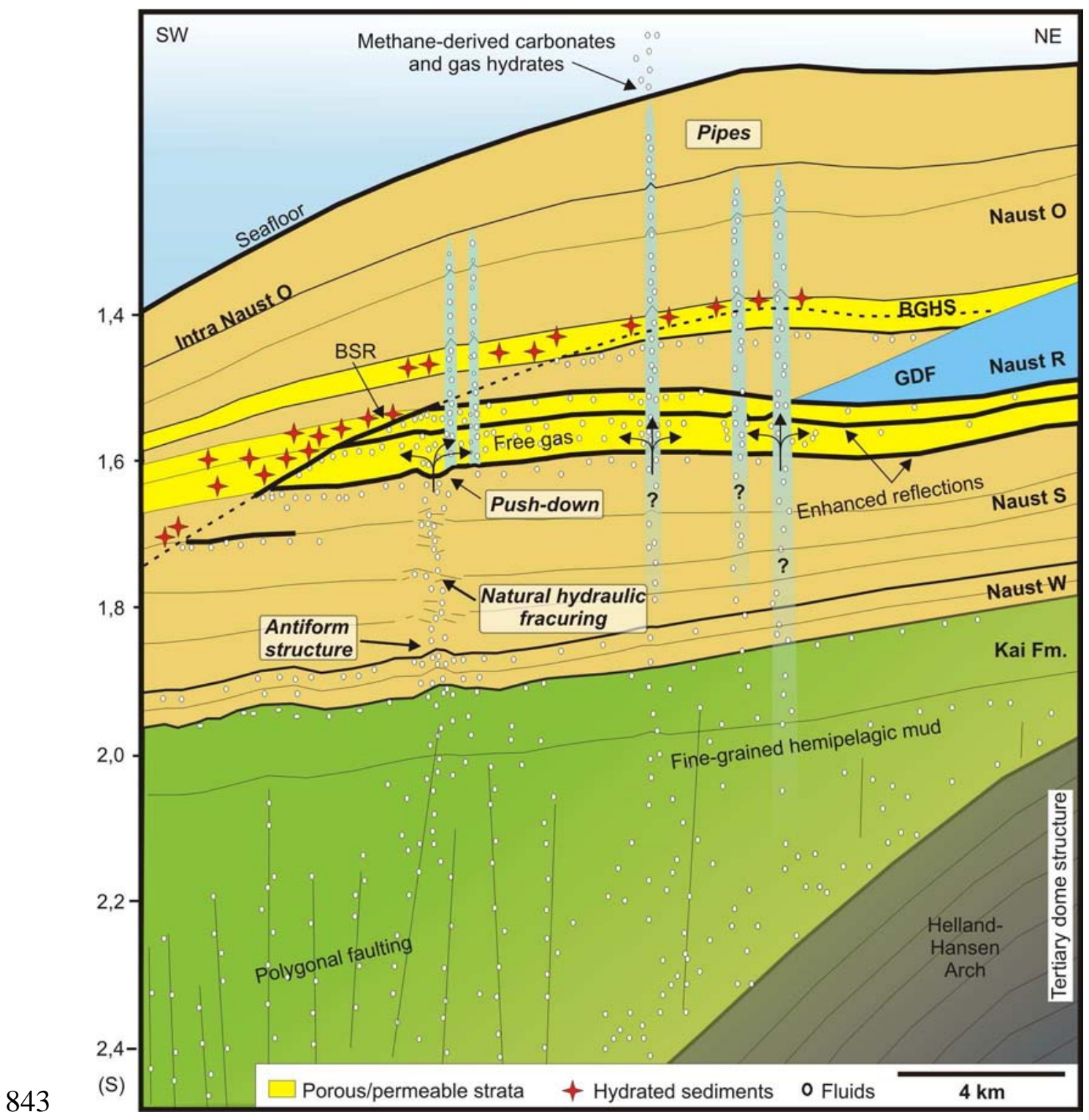

844 Figure 9: Conceptual model of the gas hydrate and fluid flow system showing interrelations between 845 deeper geological structures and shallower fluid migration pathways. 